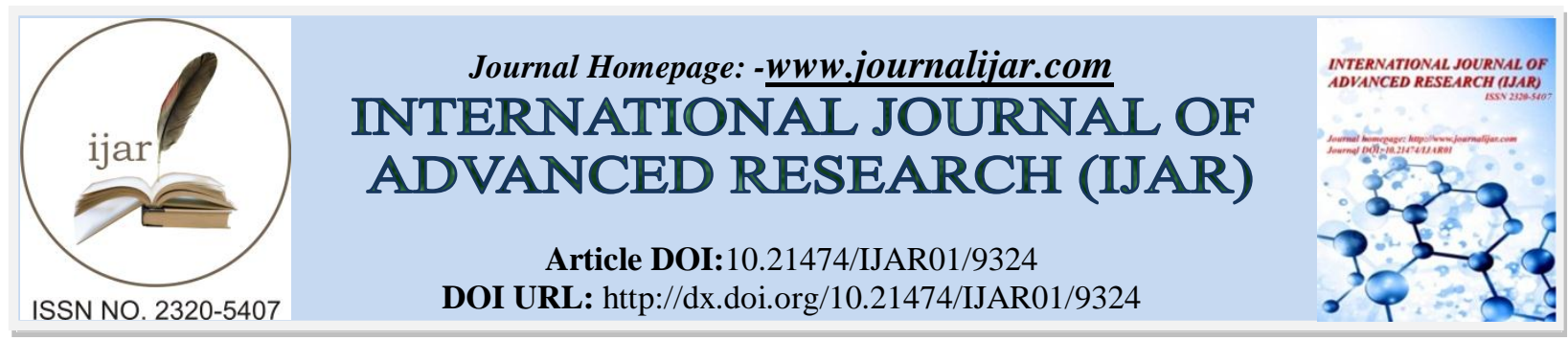

RESEARCH ARTICLE

\title{
HETEROSIS ANALYSIS FOR SEED QUALITY TRAITS IN SPRING BARLEY
}

Sana Medimagh and Mouldi El Felah.

Field Crop Laboratory, National Agronomic Research Institute of Tunisia (INRAT), Street Hedi Karray, 1004 El Manzah, University of Carthage, Tunisia.

\section{Manuscript Info}

\section{Manuscript History}

Final Accepted: 04 June 2019

Published: July 2019

Key words:-

Breeding, barley, diallel, heterosis, grain quality.
Received: 02 May 2019

\begin{abstract}
The purpose of this study was to identify and select best parents and best hybrid combinations through the study of heterosis and the combining ability of six spring barley varieties (Martin, Taj, Ardhaoui, Sahli, Rihane and Salmas) and their $F_{1}$ 's progenitors among a $6 \times 6$ complete diallel fashion. The experiment was done at Beja INRAT experimental station. Spike length, grain number per spike, thousand kernel weight, beta glucan content and protein content were investigated. Results for analysis of variance revealed highly significant differences among all the $F_{1}$ hybrid means and their respective six parental values for all the characters studied. The best crosses were (Sahli x Salmas) for protein content, (Taj x Salmas) for grain number per spike, (Sahli x Ardhaoui) for thousand kernel weight and (Martin $\mathrm{x}$ Taj) for beta glucan content. Martin x Salmas is the best specific cross for thousand kernel weight. It had been showed that it is very difficult to transgress characters such as quality from improved genotypes to local landraces. On the basis of GCA effects, 5 parents, Taj, Ardhaoui, Sahli, Rihane and Salmas were found good general combiners for seed quality traits. Among the included parents in the investigated genotypes, local cultivar Sahli is the proven positive common genitor to improve grain quality.
\end{abstract}

Copy Right, IJAR, 2019,. All rights reserved.

\section{Introduction:-}

Barley (Hordeum vulgare L.) is an annual plant, belonging to the Gramineae family, and is a diploid specie having chromosome number $2 n=2 x=14$. Spring barley is the second major cereal crop in Tunisia after wheat. It is widely used for human food, stock feed, as well as for malting and brewing. The national barley improvement program has been focused essentially on grain yield improvement than on quality product (Medimagh et al., 2012).

Diallel analysis can provide the necessary genetic information for breeding programs (Hill et al. 2001). It is a mating design to predict combining ability of the parents involved the inheritance of traits. The concept of combining ability was enunciated by Sprague and Tatum (1942). Heterosis or hybrid vigor is manifested by $\mathrm{F}_{1}$ hybrids. The magnitude of hybrid vigor is normally presented in terms of mid-parent heterosis (MPH) or superiority of the $\mathrm{F}_{1}$ hybrid over its parental mean and best-parent heterosis $(\mathrm{BPH})$ or superiority of the $\mathrm{F}_{1}$ hybrid over its better parent. However, the significance of MPH and BPH in each cross has rarely been tested (Soehendi and Srinives, 2005). Hybrid breeding is a novel technique in autogamous cereals, such as wheat and barley, and due to the yet low heterosis, hybrid breeding mostly remains a spin-off from line breeding (Timm et al. 2017). 
This study aims to investigate general and specific combining ability effects and the level of the heterosis and the heterobeltiosis on seed quality traits of six spring barley varieties and their $\mathrm{F}_{1}$ 's hybrids.

\section{Materials and Methods:-}

Plant material used in this study consisted of set of six diverse genotypes of spring barley (Hordeum vulgare L.), namely Martin, Taj, Ardhaoui, Sahli, Rihane and Salmas crossed in a complete diallel design and their thirty $\mathrm{F}_{1}$ crosses. All these $30 \mathrm{~F}_{1}$ hybrids along with their six parental cultivars were planted in complete randomized block design (CRBD) with three replications under rainfed conditions at the National Agricultural Research Institute of Tunisia (INRAT) research location in Beja. The treatments were seeded in rows of $1.5 \mathrm{~m}$ length spaced $0.25 \mathrm{~m}$.

Parents were chosen on the basis of the following criteria: variety with a long history of cultivation; a newly improved successfully grown variety and local landrace.

Significance testing's of different genotypes of $F_{1}$ cross were evaluated for increase or decrease of $F_{1}$ hybrids over mid-parent heterosis (MPH) as well as best-parent heterosis (BPH) for each studied traits according to the procedure of Matzingar et al. (1962) as follows:

Mid-parent heterosis $(\mathrm{MPH})$ or Heterosis $(\%)=\left(\mathrm{F}_{1}-\mathrm{MP}\right) / \mathrm{MP} \times 100$

Best-parent heterosis $(\mathrm{BPH})$ or Heterobeltiosis $(\%)=\left(\mathrm{F}_{1}-\mathrm{BP}\right) / \mathrm{BP} \times 100$

Where: $\mathrm{F}_{1}=$ mean observation of the $\mathrm{F}_{1}$ progenies from the total of plants

$\mathrm{MP}=$ Mid-parental value of the particular $\mathrm{F}_{1}$ cross $\left(\mathrm{P}_{1}+\mathrm{P}_{2}\right) / 2$

$\mathrm{BP}=$ Best-parent value of the particular $\mathrm{F}_{1}$ cross

Data were recorded on three randomly selected plants for beta glucan content, protein content, spike length (cm), grain number per spike and thousand kernel weight $(\mathrm{g})$. They were subjected to statistical analysis of variance using GenStat 7.1 computer software. The data were further subjected to combining ability analysis as outlined by Griffing's (1956) Model-I, Method-I using AGROBASE software (Agronomix, 1999).

The results from the field experiments are represented on the basis of significance at 5 and $1 \%$ levels. Significant differences were further subjected to least significance difference test (LSD).

\section{Results and Discussion:-}

The values of the different seed traits of 36 genotypes were subjected to analysis of variance. The results (Table 1) revealed highly significant $(\mathrm{p}<0.01)$ differences among the parents and their $\mathrm{F}_{1}$ hybrids for all the studied traits. This result is a consequence of the existence of genetic differences between parents (Akgun and Topal 2011).

Mid-parent heterosis (MPH) and best-parent heterosis (BPH) for spike length (SL), grain number per spike (GNS), thousand kernel weight (TKW), beta glucan content (BGC) and protein content (PC) were also given (Table 2).

The combined analysis of different traits of barley based on Griffing's method 1 (Model A) in a $6^{*} 6$ diallel crosses are presented in Table 3.

\section{Spike length (SL)}

For the spike length trait, the heterosis effect was remarkably present at the crossing Sahli x Salmas $(\mathrm{MPH}=19.45$ and BPM = 14.78) and crossing Martin x Sahli $(\mathrm{MPH}=16.99$ and BPH = 14.96); (Table 2). This parameter is important to select grain yielder varieties and not forage barleys. Parental forms studied in terms of spike length have submitted a higher proportion of dominant alleles and an almost symmetrical distribution of positive and negative alleles.

Ardhaoui seems be the best combiner for SL (Table 3).

In durum wheat, Dhonukshe and Rao (1979) reported heterosis ranging from -4 to $17.6 \%$, and very low heterobiotosis, whereas for Ahmad et al. (1979), the heterosis with respect to the best line was 48.2\%. These authors conclude that the heterosis of this character contributes to the heterosis of grain yield.

The significance of this component determines if the deviation of $F_{1}$ from the average parents changes from one parent to other parent (Aghamiri et al. 2012). An increase in spike length both in wheat and multi- and two-rowed barley is among the most promising approaches to breeding for increased yield (Madic et al. 2012; Medimagh et al. 2016). The selection of the spike length would be difficult to achieve in the first generations of selection 
(Subhaschandra 2007). Rihane is formally a good combiner to improve this character and consequently the number of grain per spike. These genotypes selected for grain production were used essentially for feed and food (El Felah and Medimagh 2005).

\section{Grain number per spike (GNS)}

The heterosis effect was mainly conditioned by a greater grain number per spike (GNS) for the crossover Salmas $\mathrm{x}$ Rihane (29.86) and Martin x Sahli (27.55) with a negative heterobiotosis (-4.10); (Table 2). Thus, the maximum effect of heterosis can only be predicted at $30 \%$ for GNS, an agronomic trait highly sought after by tunisian grain producers.

According to Fejer and Fedak (1978), the heterosis of GNS is relative to the average parent in barley, reached $21 \%$ in seedlings. For Singh and Behl (1991), it is the heterosis of the GNS that contributes to the heterosis of grain yield.

The combined ability effects (CA) related to the spike and grain yield components of two and six rows barley varieties were the highest for the GNS compared to CA calculated for the other traits (Table 3). Results showed that Rihane is the best combiner. This explains partly, the applied classical pedigree breeding method to stabilize grain yield potential. This ability to break this high character at its offsprings gives it a top priority in our breeding program as an important parent, when we want to improve the productivity in terms of grain yield. Moreover, the two-rowed varieties Taj and Salmas cannot compete with polystichum forms in terms of GNS. The negative value for GNS (Table 3) in early generations suggested a higher effect of recessive genes (Madic et al. 2012). Two rowed parents showed pleitropic gene effects due to the grain number per spike unlike six-row barleys. This shows that the row type plays a key role in the trait expression through dominance and epistasic effects.

\section{Thousand kernel weight (TKW)}

High heterosis values are observed for the thousand kernel weight (TKW), mainly for crosses Martin x Taj (38.69) and Martin x Salmas (51.02) and their reciprocals Taj x Martin (38.73) and Salmas x Martin (42.29). Hence the possible structural differences of the heterosis effect, the highest superdominance value for TKW was obtained for the combination Martin x Salmas (38.17) and its reciprocal Salmas x Martin (30.18), confirming the results of heterosis; (Table 2). Thus, the cultivars of the green pre-revolution were generally local populations with high straw (Ardhaoui and Sahli). Moreover, Yao et al. (2013) showed the positive relationship between genetic distance and heterosis in cultivated plants. Fejer and Fedak (1978) reported heterosis relative to the average parent in barley of 23\%. The works of Singh and Chaudhary (1977) show heterosis for PMG as strongly related to yield heterosis.

TKW is a physical indicator of grain commonly used in breeding for characterization of grain weight and seems to be correlated with the head-row type (Andersson et al.1999).

\section{Beta glucan content (BGC)}

The heterosis effect was apparent for Rihane $\mathrm{x}$ Ardhaoui cross $(\mathrm{MPH}=9.26$ and $\mathrm{BPH}=8.89)$ and Taj $\mathrm{x}$ Martin cross $(\mathrm{MPH}=7.64$ and BPH = 5.84); (Table 2). Indeed, several authors (Bhadouria et al., 1976, Perenzin et al., 1987, Singh and Behl, 1991) have found relationships between the heterosis of one or more components of yield with heterosis of grain yield for wheat. The main components mentioned are the number of grains per ear and / or the weight of 1000 grains (Bhadouria et al., 1976, Jatasra et al., 1980, Singh and Behl, 1991).

Melchinger (1999) concluded that it is not possible to accurately predict the heterosis effect based on the genetic distance between forms of cross-breeding based on the selective history of parents involved in diallel crossing. It is known that the heterosis effect level of $F_{1}$ hybrids is largely determined by the degree of genetic diversity of the components of the cross. Long-term observation has shown that, in general, a low degree of genetic diversity makes the effect of heterosis insignificant, and that the use of genetically very divergent components can lead to an intermediate inheritance. In this respect, the optimal genetic distance for the "management" of the heterosis effect should be defined, applying effective breeding methods.

It was shown in later work that Martin, a selection in local mountain-barley populations, is very good from the point of view of quality storage proteins in the kernels, despite its low heritability (Bettaieb-Ben Kaab et al.2005).

\section{Protein content (PC)}

The heterosis effect was remarkably present at the cross Taj x Ardhaoui where we found maximum heterosis (21.7) and heterobeltiosis (17.16) and the cross Rihane $\mathrm{x}$ Taj $(\mathrm{MPH}=19.06$ and BPH = 14.18) in Taj x Ardhaoui; (Table 2). 
Several heterosis genetic studies of quantitative traits for different cultures have shown that heterosis is the result of partial dominance at complete, superdominance and epistasis. It can be the combination of all this array of gene manifestations (Comstock and Robinson, 1952). A real superdominance is very hard to find for quantitative characters. Heterosis may also be due to specific positive effects of the cytoplasm of the female parent on the nuclear side of the paternal parent.

Barley protein and beta-glucan content are polygenic traits (Islam et al., 2006; Nasrallah et al., 2007). Due to the presence of more than one type of dominant gene action and double dominant epistatic effects present in the expression of this character, the selection of these characters in the first generation will be difficult. Selection based on progeny performance operator only additive component of genetic variance of this trait through a diallel cross led to all possible combinations among segregating selected strains could recover homozygous lines the most efficient. The BGC is controlled by a simple additive genetic system for barley and oats (Holthaus et al., 1996).

For most parameters observed in the present study, we note the importance of additive effects and dominance in the control of the variance and the expression of these characters. These results are consistent with those of Yilmaz and Konak (2000). This suggests that the spatial variability in the test was not due to natural variability of soil, but rather basic plot variability across the experimental device (Hung et al., 2012).

\section{Conclusion:-}

This research investigation exhibited that all genotypes studied had genetic characteristics that distinguish them from each other. It had been showed that is very difficult to transgress characters such as yield or quality from improved genotypes to local landraces. Characters controlled additively provide a mechanism for reliable selection in the early generations of selection. Among the included parents in the investigated genotypes, local cultivar Sahli and improved Rihane are the proven positive common genitors to improve grain yield potential. The genetic gain through the maternal inheritance received from female relatives, explained that suitability of general and specific skills of parents are of importance to teach their offsprings adaptation to extreme environments. The BGC as a high quality value added trait will be considered more in the future to identify barley lines adapted to new socioeconomically demanding environments. In conclusion, breeders would need to develop plant breeding based on a database of available markers and challenges of good phenotypic information. Investigation about heterosis is useful for the good orientation of the national barley breeding programme.

\section{Acknowledgements:-}

We would like to thank ICARDA for help in seed quality analysis at the Seed Health Unit at ICARDA, AleppoSyria.

Table 1:-Mean squares of various seed traits in 6x6 diallel crosses of barley.

\begin{tabular}{|l|l|c|c|c|c|c|}
\hline \multicolumn{1}{|c|}{ Source of variation } & DF & SL & GNS & TKW & BGC & PC \\
\hline Genotypes & 35 & $6.586^{* *}$ & $1313.07 * *$ & $175.894 * *$ & $0.175 * *$ & $6.739 * *$ \\
\hline Replication & 2 & 1.967 & 243.58 & 0.348 & 0.037 & 0.044 \\
\hline Error & 70 & 1.571 & 45.59 & 0.003 & 0.000 & 0.000 \\
\hline Mean & & 21.17 & 47.33 & 55.31 & 5.99 & 12.98 \\
\hline
\end{tabular}

**: significant at the $1 \%$ levels of probability;

SL: spike length; GNS: grain number per spike; TKW: thousand kernel weight; BGC: beta glucan content; PC: protein content; DF: degree of freedom.

Table 2:-Mid-parent heterosis (MPH) and best-parent heterosis (BPH) for spike length (SL), grain number per spike (GNS), thousand kernel weight (TKW), beta glucan content (BGC) and protein content (PC)effects in seed related traits in 6x6 diallel crosses of barley

\begin{tabular}{|c|c|c|c|c|r|r|r|r|r|c|}
\hline \multirow{2}{*}{ Crosses } & \multicolumn{2}{|c|}{ SL } & \multicolumn{2}{c|}{ GNS } & \multicolumn{2}{c|}{ TKW } & \multicolumn{2}{c|}{ BGC } & \multicolumn{2}{c|}{ PC } \\
\cline { 2 - 12 } & MPH & \multicolumn{1}{|c|}{ BPH } & \multicolumn{1}{c|}{ MPH } & \multicolumn{1}{c|}{ BPH } & \multicolumn{1}{c|}{ MPH } & \multicolumn{1}{|c|}{ BPH } & MPH & BPH & MPH & BPH \\
\hline Martin x Taj & 8,98 & 4,46 & $-34,06$ & $-53,61$ & 38,69 & 19,99 & 4,58 & 2,84 & 9,02 & 8,21 \\
\hline Martin x Ardhaoui & 5,87 & $-1,50$ & 14,58 & 13,70 & 13,33 & 1,53 & 3,83 & 2,35 & $-4,69$ & $-7,57$ \\
\hline Martin x Sahli & 16,99 & 14,96 & 27,55 & 26,26 & 21,82 & 14,08 & 1,29 & $-4,72$ & $-2,66$ & $-3,03$ \\
\hline Martin x Rihane & 1,91 & 1,74 & 3,34 & 3,08 & 3,88 & $-4,22$ & 5,55 & 4,39 & 4,31 & 0,76 \\
\hline Martin x Salmas & 13,51 & 10,96 & $-35,89$ & $-52,58$ & 51,02 & 38,17 & $-1,22$ & $-2,42$ & $-0,38$ & $-0,76$ \\
\hline
\end{tabular}




\begin{tabular}{|c|c|c|c|c|c|c|c|c|c|c|}
\hline Taj x Martin & 12,64 & 7,97 & $-34,06$ & $-53,61$ & 38,73 & 20,03 & 7,64 & 5,84 & 10,52 & 9,70 \\
\hline Taj x Ardhaoui & 4,25 & 1,05 & $-39,13$ & $-57,36$ & $-2,13$ & $-5,92$ & $-0,08$ & $-0,33$ & 21,70 & 17,16 \\
\hline Taj x Sahli & 6,26 & 0,16 & $-42,24$ & $-59,59$ & $-1,520$ & $-9,557$ & $-5,73$ & $-9,89$ & 3,39 & 2,24 \\
\hline Taj x Rihane & 15,67 & 10,68 & $-35,03$ & $-54,36$ & 13,039 & 5,441 & 0,59 & 0,00 & 10,50 & 5,97 \\
\hline Taj x Salmas & 2,85 & 0,80 & 0,00 & $-7,53$ & 16,986 & 9,981 & $-2,06$ & $-4,84$ & 3,39 & 2,24 \\
\hline Ardhaoui x Martin & 9,73 & 2,09 & 8,95 & 8,12 & 16,58 & 4,44 & 1,10 & $-0,33$ & $-1,56$ & $-4,54$ \\
\hline Ardhaoui x Taj & $-5,79$ & $-8,68$ & $-56,52$ & $-69,54$ & 6,69 & 2,56 & $-0,25$ & $-0,50$ & $-13,18$ & $-16,42$ \\
\hline Ardhaoui x Sahli & 8,42 & $-0,75$ & 3,80 & 3,53 & 8,63 & 3,58 & $-0,40$ & $-5,02$ & $-25,49$ & $-27,48$ \\
\hline Ardhaoui x Rihane & 5,08 & $-2,39$ & 13,26 & 12,69 & 11,63 & 8,17 & 2,02 & 1,68 & $-31,17$ & $-31,45$ \\
\hline Ardhaoui x Salmas & $-2,52$ & $-7,33$ & $-57,93$ & $-69,03$ & 18,79 & 16,06 & 2,84 & 0,17 & 14,51 & 11,45 \\
\hline Sahli x Martin & 2,83 & 1,04 & 2,55 & 1,51 & 14,22 & 6,96 & 1,29 & $-4,72$ & 4,18 & 3,79 \\
\hline Sahli x Taj & 14,72 & 8,13 & $-29,24$ & $-50,50$ & 2,10 & $-6,23$ & $-5,25$ & $-9,44$ & 13,96 & 12,69 \\
\hline Sahli x Ardhaoui & $-8,75$ & $-16,47$ & $-9,37$ & $-9,59$ & $-34,28$ & $-37,33$ & $-7,90$ & $-12,18$ & 8,23 & 5,34 \\
\hline Sahli x Rihane & 15,96 & 14,13 & 15,01 & 14,14 & 11,61 & 9,75 & 1,20 & $-3,80$ & 11,81 & 8,40 \\
\hline Sahli x Salmas & 19,45 & 14,78 & $-39,52$ & $-55,55$ & 17,12 & 14,23 & $-4,91$ & $-11,57$ & 14,50 & 14,50 \\
\hline Rihane x Martin & 2,44 & 2,26 & 1,80 & 1,54 & 0,36 & $-7,47$ & 1,96 & 0,84 & 3,53 & 0,00 \\
\hline Rihane x Taj & 11,33 & 6,54 & $-35,76$ & $-54,87$ & 14,76 & 7,05 & 1,09 & 0,50 & 19,06 & 14,18 \\
\hline Rihane $\mathrm{x}$ Ardhaoui & $-2,50$ & $-9,43$ & 13,26 & 12,69 & 5,76 & 2,49 & 9,26 & 8,89 & 5,26 & 4,84 \\
\hline Rihane x Sahli & $-0,53$ & $-2,09$ & $\begin{array}{l}-5,34 \\
\end{array}$ & $-6,06$ & $-0,13$ & $-1,79$ & $-0,24$ & $-5,17$ & 7,87 & 4,58 \\
\hline Rihane x Salmas & 14,21 & 11,46 & $-38,19$ & $-54,36$ & 20,12 & 19,12 & $-1,64$ & $-3,88$ & 13,38 & 9,92 \\
\hline Salmas x Martin & 4,50 & 2,16 & $-40,77$ & $-56,18$ & 42,29 & 30,18 & $-1,05$ & $-2,24$ & 8,74 & 8,33 \\
\hline Salmas x Taj & $-1,38$ & $-3,35$ & 3,49 & $-4,30$ & 11,40 & 4,73 & $-3,43$ & $-6,18$ & 1,13 & 0,00 \\
\hline Salmas x Ardhaoui & 15,27 & 9,58 & $-39,31$ & $-55,33$ & 24,36 & 21,50 & 1,64 & $-1,01$ & 10,59 & 7,63 \\
\hline Salmas x Sahli & 8,73 & 4,48 & $-41,58$ & $-57,07$ & 27,92 & 24,76 & $-6,55$ & $-13,09$ & 12,21 & 12,21 \\
\hline Salmas x Rihane & 13,36 & 10,63 & 29,86 & $-4,10$ & 25,47 & 24,42 & 3,02 & 0,67 & 17,32 & 13,74 \\
\hline
\end{tabular}

Table 3:-Estimation of general combining ability (GCA) effects for spike length (SL), grain number per spike (GNS), thousand kernel weight (TKW), beta glucan content (BGC) and protein content (PC) in 6x6 diallel crosses of spring barley

\begin{tabular}{|l|l|l|l|l|l|l|}
\hline Traits & Martin & Taj & Ardhaoui & Sahli & Rihane & Salmas \\
\hline SL & -0.279 & 0.434 & 0.470 & -0.574 & -0.363 & 0.312 \\
\hline GNS & 9,111 & $-19,222$ & 6,889 & 8,055 & 10,944 & $-15,778$ \\
\hline TKW & -0.576 & 3.564 & -1.623 & -4.352 & -1.657 & 4.644 \\
\hline BGC & 0.017 & -0.023 & 0.035 & 0.143 & 0.071 & -0.243 \\
\hline PC & -0.578 & 1.384 & -0.134 & 0.217 & -0.430 & -0.458 \\
\hline
\end{tabular}

\section{References:-}

1. Aghamiri S. M., Mostafavi K. and Mohammadi A. (2012). Genetic study of agronomic traits in barley based diallel cross analysis. Advances in Environmental Biology. 6(1): 62-68.

2. Agronomix Software Inc., Canada, 1999.

3. Ahmad Z., Kumar P., Katiyar R.P. and Gupta R.R. (1979). Heterosis in macaroni wheat. Indian Journal of Genetics and Plant Breeding. 39: 279 - 284.

4. Akgun N. and Topal A. (2011). Regression analysis of grain weight per plant in barley crosses. Bulgarian Journal of Agricultural Science. 17: 773-776.

5. Andersson A. A. M., Elferson C., Andersson R., Regner S. and Aman P. (1999). Chemical and physical characteristics of different barley samples. Journal of the Science of Food and Agriculture. 79: 979-986.

6. Bettaieb-Ben Kaab L., El Felah M., Ghorbal M. H. and Laurière M. (2005). Relationships between some hordein components and quality properties in two Tunisian barley varieties as influenced by nitrogen fertilization. Czech Journal of Genetics and Plant Breeding. 41 (1): 11-16.

7. Bhadouria S. S., Singh K. P. and Shrivastava P. S. (1976). Heterosis in common wheat Triticum aestivum. Jawaharlal Nehru Krishi Vishwa Vidyalaya Research Journal. 10: 219- 225.

8. Comstock R. E. and Robinson H. F. (1952). Estimation of the average dominance of genes. Heterosis. pp: 494516. 
9. Dhonukshe B. L. and Rao M. V. (1979). Heterosis in durum wheat. Indian Journal of Genetics and Plant Breeding. 39: 285 - 291.

10. El Felah M. and Medimagh S. (2005). Food barley in Tunisia. In Grando, S. and G. H. MacPerson, (Eds.), Food Barley: Importance, Uses and Local Knowledge. Proceedings of the International Workshop on Food Barley Improvement, Aleppo, Syria, ICARDA 29-35.

11. Fejer S.O. and Fedak G. (1978): Heterosis in Conventional and Short Straw Barley Crosses. Zeitsch fur Pflanzenzuchtung. 80: 250-260.

12. Griffing B. 1956. Concept of general and specific combining ability in relation to diallel crossing system. Australian Journal of Biological Sciences. 9: 463-493.

13. Hill J., Wagoire W. W., Oritz R. and Stlen O. (2001). Analysis of a combined $F_{1} / F_{2}$ diallel cross in wheat. Theoretical and Applied Genetics. 102(6-7): 1076-1081.

14. Holthaus J. F., Holland J. B., White P. J. and Frey K. J. (1996). Inheritance of b-glucan content of oat grain. Crop Science. 36:567-572.

15. Hung H. Y., Browne C., Guill K., Coles N., Eller M., Garcia A., Lepak N., Hancock S. M., Rosas M. O., Salvo S., Upadyayula N., Buckler E. S., Garcia S. F., McMullen M. D., Rocheford T. R. and Holland J. B. (2012).The relationship between parental genetic or phenotypic divergence and progeny variation in the maize nested association mapping population. Heredity, 108: 490-499.

16. Islam M., White H. and Kone N. T. (2006). Inheritance of beta-glucan content of hulless barley grain. Journal of Plant Genetics. 21: 457-463.

17. Jatasra D.S., Parodar S. and Waldia R. S. (1980). Hybrid vigor in an 8 parent diallel cross for yield and its components in wheat. Haryana Agricultural University Journal of Research. 10: 317- 323.

18. Madic M., Knezevic D., Paunovic A. and Durovic D. (2012). Genetic analysis of spike traits in two- and multirowed barley crosses. Genetika. 44(3): 475-482.

19. Matzingar, D.F, Mann, T.J and Cockerham, C.C. (1962). Diallel crosses in Nicotiana tabaccum. Crop Science. 2: 383-386.

20. Medimagh S., El Felah M. and El Gazzah M. (2012). Barley breeding for quality improvement in Tunisia. African Journal of Biotechnology. 11(89): 15516-15522. ISSN 1684-5315.

21. Medimagh S., El Felah M. and El Gazzah M. (2016). General and specific combining ability analysis for quantitative characters in Tunisian Spring Barley. Transylvanian Review. 24 (11): 3210-3216.

22. Melchinger A.E. (1999). Genetic diversity and heterosis. In: Coors JG and Pandey S (eds) The Genetics and Exploitation of Heterosis in Crops, CCSA, ASA, and SSA: Madison, WI, USA. pp 99-118.

23. Nasrallah A. M., Kumar G. and Kuchel B. (2007). Gene action for protein content in hulless barley (Hordeum vulgare L.). Journal of Plant Genetics. 13: 88-92.

24. Perenzin M., Corbellini M. and Borghi B. (1987). Growth analysis of ten bread wheat hybrids Triticum aestivum produced with a chemical hybridizing agent. Genetic Agrar. 41: 163-172.

25. Singh R. K. And Behl R. K. (1991). Genetic divergence in relation to combining ability and transgression in wheat. Journal of Genetics and Breeding. 45 (2): 147- 150.

26. Soehendi R. and Srinives P. (2005). Significance of heterosis and heterobeltiosis in an F1 hybrid of mungbean (Vigna radiata L.) Wilczek) for hybrid seed production. SABRAO Journal of Breeding and Genetics 37(2) 97105.

27. Sprague G. F. and Tatum L. A. (1942). General vs specific combining ability in single crosses of corn. Journal of the American Society of Agronomy. 34: 923-932.

28. Subhaschandra B. (2007). Genetic analysis in tetraploid wheat. M.Sc. thesis. College of Agriculture, University of Agricultural Sciences, Dharwad. 69 p.

29. Timm B., Wolfgang F., Kai P., Voss-Fels., Matthias F., Rod J. Snowdon, and Wittkop B. (2017). Heterosis for Biomass and Grain Yield Facilitates Breeding of Productive Dual-Purpose Winter Barley Hybrids. Crop Science. 57:1-14.

30. Yao W. H., Zhang Y. D., Kang M. S., Chen H. M., Liu L., Yu L. J. and Fan X. M. (2013). Diallel analysis models: A comparison of certain genetic statistics. Crop Science. 53: 1481-1490.

31. Yilmaz Z. R. and Konak C. (2000). Heterotic effects regarding salt tolerance in some characters of barley. Turkish Journal of Agriculture and Forestry. 24 (6): 643-648. 